\title{
[E] EDUMASPUL
}

Vol. 4 - No.1, year (2020), page 280 - 287

| ISSN 2548-8201 (Print)| 2580-0469) (Online)|

\section{PERBEDAAN PENINGKATAN SELF-EFFICACY SISWA YANG DIBERI PEMBELAJARAN MATEMATIKA DENGAN PENDEKATAN PMR DAN PENDEKATAN PENEMUAN TERBIMBING}

\author{
Weni Ariyanti Lubis ${ }^{1}$, Suwarno Ariswoyo ${ }^{2}$, Edi Syahputra ${ }^{3}$ \\ 1,2Universitas Muslim Nusantara Al-Washliyah, Indonesia. \\ 3Universitas Negeri Medan,Indonesia. \\ * Corresponding Author. E-mail: ${ }^{1}$ Weniariyanti2309@gmail.com
}

Receive: 02/03/2020

Accepted: 05/03/2020

Published: 11/03/2020

\begin{abstract}
Abstrak
Penelitian ini bertujuan untuk menelaah Perbedaan peningkatan self-efficacy antara siswa yang diberi pembelajaran matematika dengan pendekatan PMR dan pendekatan Penemuan Terbimbing. Jenis penelitian ini adalah quasi eksperimen (eksperimen semu). Populasi dalam penelitian ini adalah seluruh siswa kelas XI SMA Alwashliyah 3 Medan T.A 2018/2019 berjumlah 90 siswa. Pemilihan sampel penelitian ditentukan dengan cara acak memilih dua kelas. Kemudian didistribusikan merata secara heterogen pada tiap kelas yaitu kelas eksperimen 1 dan kelas eksperimen 2. Kelas eksperimen 1 adalah kelas yang dikenakan perlakuan dengan menggunakan pendekatan PMR dan kelas eksperimen 2 adalah kelas yang dikenakan dengan pembelajaran penemuan terbimbing Instrumen yang digunakan dalam pengumpulan data yaitu dengan angket self - efficacy. Hasil penelitian menunjukkan terdapat perbedaan peningkatan self- efficacy antara siswa yang diberi pembelajaran matematika dengan pendekatan PMR dan Pendekatan Penemuan Terbimbing .
\end{abstract}

Kata Kunci: Self-Efficacy matematika, PMR, Penemuan Terbimbing.

diffrences in the improvement of self-efficacy provided by mathematics learning with the PMR approach and Discovery learning Approach

\begin{abstract}
This study aims to examine the differences in increasing self-efficacy between students who are given mathematics learning with the PMR approach and the Guided Discovery approach. This type of research is quasi-experimental (quasi-experimental). The population in this study were all students of class XI Alwashliyah 3 Medan T.A 2018/2019, amounting to 90 students. The selection of research samples is determined by randomly selecting two classes. Then evenly distributed heterogeneously in each class, namely experimental class 1 and experimental class 2. Experimental class 1 is a class that is subject to treatment using assisted PMR approach and experimental class 2 is a class that is subject assisted guided learning learning. The instrument used in data collection is a self-efficacy questionnaire. The
\end{abstract}


Jurnal Edumaspul, 4 (1), Year 2020 - 281

(Weni Ariyanti Lubis, Suwarno Ariswoyo, Edi Syahputra)

results showed there were differences in the increase in self-efficacy between students who were given mathematics learning with the PMR approach and the Guided Discovery Approach.

Keywords: PMR, Discovery Learning, Self-efficacy.

\section{Pendahuluan}

Permendiknas No. 22 tahun 2006 tentang Standar Isi Mata Pelajaran Matematika menyatakan bahwa tujuan mata pelajaran matematika diajarkan di SMA yakni : 1. Memahami konsep matematika, menjelaskan keterkaitan antarkonsep dan mengaplikasikan konsep atau algoritma, secara luwes, akurat, efisien, dan tepat, dalam pemecahan masalah. 2. Menggunakan penalaran pada pola dan sifat, melakukan manipulasi matematika dalam membuat generalisasi, menyusun bukti, atau menjelaskan gagasan dan pernyataan matematika. 3. Memecahkan masalah yang meliputi kemampuan memahami masalah, merancang model matematika, menyelesaikan model dan menafsirkan solusi yang diperoleh. 4. Mengkomunikasikan gagasan dengan symbol, tabel, diagram, atau media lain untuk memperjelas keadaan atau masalah. 5. Memiliki sikap menghargai kegunaan matematika dalam kehidupan, yaitu memiliki rasa ingin tahu, perhatian, dan minat dalam mempelajari matematika, serta sikap ulet dan percaya diri dalam pemecahan masalah.

Untuk mencapai kemampuankemampuan seperti yang disebutkan di atas, dibutuhkan pembelajaran yang mengacu pada pemberian kesempatan kepada siswa melakukan eksplorasi, menemukan, menganalisis dan mengumpulkan data.Oleh karena itu, siswa akan memiliki kesempatan mengembangkan kemampuan berfikirnya dalam menggambarkan dan memecahkan masalah baik itu masalah matematika maupun masalah yang ditemukannya dalam kehidupannya sehari-hari.

Hal ini sejalan dengan tujuan pembelajaran matematika yang dirumuskan oleh Midgett, C. W., \& Eddins, S. K. (2001).yaitu: 1) belajar untuk berkomunikasi (mathematical communication), 2) belajar untuk bernalar (mathematical reasoning), 3) belajar untuk memecahkan masalah (mathematical connection), 5) pembentukan sikap positif terhadap matematika (positive attitudes towards mathematics). Pada kenyataannya, pentingnya belajar matematika tidak sesuai dengan harapan, hal ini ditunjukkan dengan rendahnya nilai kemampuan matematika yang dapat dilihat dari hasil studi yang dilakukan oleh Programme for International Student Assesment (PISA). Menurut Lijing, J., \& Yingnan, J. (2017)PISA kemampuan matematika siswa-siswi Indonesia berada di peringkat 63 dari 69 negara atau dapat dikatakan peringkat ke enam dari bawah. Rendahnya prestasi matematika siswa salah satunya disebabkan oleh kurangnya kesempatan yang diberikan kepada siswa untuk menemukan dan melihat pola serta melakukan pemecahan masalah. Banyak guru memulai pembelajaran matematika dengan penjelasan tentang ide-ide yang terdapat pada halaman buku yang dipelajari, kemudian diikuti dengan menunjukkan kepada siswa bagaimana mengerjakan latihan soal. Bahkan ketika siswa berkegiatan, guru masih menuntun siswa bagaimana menggunakan materi yang dipelajari untuk mengerjakan latihan. Fokus utama dari pelajaran adalah mendapatkan jawaban. Para siswa menyandarkan kepada guru untuk 
Jurnal Edumaspul, 4 (1), Year 2020 - 282

(Weni Ariyanti Lubis, Suwarno Ariswoyo, Edi Syahputra)

menentukkan apakah jawabannya benar. Anak-anak yang mendapat pengalaman seperti ini akan mempunyai pandangan bahwa matematika adalah sederetan aturan yang tidak ada polanya yang dibawa oleh guru. Akibatnya anak-anak dijauhkan dari sumber pengetahuan yang sebenarnya dan tidak mampu memecahkan masalah tanpa bantuan dan campur tangan guru.

Menurut Usman, H., \& Akbar, R. P. S. (2006) Matematika sekolah adalah matematika yang diajarkan di satuan pendidikan dengan materi matematika dan pola pikir yang disesuaikan dengan kebutuhan penerapan dalam kehidupan sehari-hari dan perkembangan ilmu pengetahuan. Pendidikan Matematika Realistik (PMR) adalah sebuah pendekatan belajar matematika yang dikembangkan sejak tahun 1971 oleh sekelompok ahli matematika dari Freudentha Institute, Utrecht University di Negeri Belanda. Pendekatan ini didasarkan pada pemikiran Bos, H. J. (1992). Hans Freudenthal (19051990) bahwa matematika adalah kegiatan manusia. Menurut pendekatan ini, kelas matematika bukan tempat memindahkan matematika dari guru kepada siswa, melainkan tempat siswa menemukan kembali ide dan konsep matematika melalui eksplorasi masalah - masalah realistis. Ketermaknaan konsep matematika merupakan konsep utama dari PMR. Proses pembelajaran siswa hanya akan terjadi jika pengetahuan yang dipelajari bermakna bagi siswa. Pembelajaran matematika dengan Pendekatan Matematika Realistik mempunyai ciri-ciri sebagai berikut: kontekstual, inventif, kreatif, berpikir alternative, komunikatif dan argumentative, koperatif dan demokratif. PMR bercirikan kontekstual karena bahanbahan ajar diambil dari bahan- bahan yang dekat, dikenal dan menarik perhatian siswa. Siswa ditantang untuk menyampaikan pemikirannya sedemikian rupa sehingga diharapkan dapat meyakinkan pendengar. Untuk itu, dilatih untuk mengungkapkan pemikiran atau gagasan secara urut, lengkap dan meyakinkan.

Selain Pendekatan Matematika Realistik (PMR), Pendekatan Penemuan Terbimbing juga diperlukan dalam pembelajaran matematika. Menurut penjelasan Trianto, menyatakan "discovery merupakan bagian dari inquiry, atau inquiry merupakan perluasan proses discovery yang digunakan lebih mendalam. Inkuiri dalam bahasa Inggris: inquiry, yang memiliki arti pertanyaan, pemeriksaan, dan penyelidikan". Dengan kata lain, dalam proses penemuan ini siswa akan dibantu oleh guru atau pun hasil diskusi dengan temannya, dan penemuan ini juga merupakan penemuan yang telah ditemukan orang lain.

Menurut Persada, A. R. (2016). mengemukakan bahwa dalam belajar penemuan siswa didorong untuk terutama belajar sendiri melalui keterlibatan aktif dengan konsep-konsep dan prinsip-prinsip, dan guru mendorong siswa mempunyai pengalaman dan melakukan eksperimen yang memungkinkan mereka menemukan prinsip-prinsip bagi diri sendiri. Dari paparan di atas, dapat diketahui bahwa pembelajaran dengan menggunakan pendekatan penemuan terbimbing lebih menekankan kepada memanipulasi objek dan lain-lain percobaan, sebelum sampai pada generalisasi dimana siswa aktif terlibat didalamnya. Dengan kata lain, siswa sendiri atau kelompok secara aktif mencari informasi baru berdasarkan informasi yang diketahui sebelumnya dengan bimbingan guru.

Selain kemampuan pemecahan masalah yang perlu dikembangkan juga adalah sikap (dalam ranah afektif) sebagaimana dalam kurikulum 2013 Standar Kemampuan Kelulusan (SKL) 
peserta didik harus memiliki sikap berakhlak mulia, berilmu, percaya diri dan bertanggung jawab. Dari SKL tersebut salah satu sikap yang harus dikembangkan dalam pembelajaran matematika adalah percaya diri (self efficacy).

Self - efficacy adalah salah satu sikap percaya diri yang merupakan aspek psikologis yang berperan terhadap keberhasilan seseorang peserta didik dalam menyelesaikan tugas yang baik. Selfefficacy (kemampuan diri) merupakan suatu keyakinan yang harus dimiliki siswa agar berhasil dalam proses pembelajaran. Ada lima karakteristik afektif yang dapat mempengaruhi hasil belajar peserta didik yaitu: sikap, minat, konsep diri, nilai dan moral. Self - efficacy adalah kepercayaan atau keyakinan seseorang bahwa ia dapat menguasai situasi dan dapat menghasilkan hasil yang positif. Kepercayaan diri akan memperkuat motivasi mencapai keberhasilan sehingga semangat dalam menyelesaikan suatu tugas yang sedang diampu oleh peserta didik.

Seseorang cenderung akan menjalankan sesuatu apabila ia merasa kompeten dan percaya diri. Selain itu akan menentukan seberapa jauh upaya yang dilakukannya, berapa lama ia bertahan apabila mendapat masalah, dan seberapa fleksibel dalam situasi yang kurang menguntungkan. Makin besar Self efficacy seseorang, makin besar upaya, ketekunan, dan fleksibilitasnya. Self efficacy juga mempengaruhi pola pikir dan reaksi emosionalnya. Seseorang dengan Self-efficacy yang rendah akan mudah menyerah, cenderung menjadi stres, depresi, dan mempunyai suatu visi yang sempit tentang apa yang terbaik untuk menyelesaikan masalah itu. Sedangkan Self- efficacy yang tinggi, akan membantu seseorang dalam menciptakan suatu perasaan tenang dalam menghadapi masalah atau aktivitas yang sukar. Namun, self-efficacy siswa masih rendah sehingga banyak siswa yang mengalami kesulitan dalam mempelajari matematika dan menganggap matematika itu pelajaran yang sulit. Disekolah sering ditemukan bahwa peserta didik masih enggan atau tidak percaya diri untuk bertanya tentang materi yang belum mereka pahami. Peserta didik juga tidak percaya diri dalam menyampaikan ide atau gagasan dalam forum diskusi ataupun dalam proses belajar yang sedang berlangsung. Sehingga keadaan tersebut sangat mempengaruhi prestasi belajar peserta didik. Oleh karena itu, kemampuan self-efficacy harus dikembangkan dalam diri siswa agar dapat memaknai proses pembelajaran matematika dalam kehidupan nyata, sehingga proses pembelajaran terjadi secara optimal.

Berdasarkan uraian diatas maka diduga akan ada perbedaan peningkatan self- efficacy siswa yang diberi pembelajaran matematika dengan pendekatan PMR dan Pendekatan Penemuan Terbimbing. Oleh karena itu, peneliti akan melakukan penelitian tentang perbedaan peningkatan self- efficacy siswa yang diberi pembelajaran matematika dengan pendekatan PMR dan penemuan Terbimbing

\section{Metode}

Penelitian ini merupakan penelitian metode eksperimen semu (quasi eksperimen) dengan desain kelompok eksperimen 1 dan eksperimen 2 pretes dan posttest (prestest posttest control group design). Pembelajaran dilaksanakan di kelas eksperimen 1 dengan pendekatan PMR dan kelas eksperimen dua dengan pendekatan penemuan Terbimbing. Sebelum pembelajaran dan sesudah pembelajaran diberikan angket untuk mengukur self-efficacy matematika siswa dengan pendekatan PMR dan Pendekatan 
Penemuan Terbimbing .Uji statistik yang digunakan pada penelitian ini adalah $\mathrm{Uji}$ Kolmogorov Sminorv $Z$ untuk uji normalitas, Uji Levene's unuk uji homogenitas dan uji hipotesis menggunakan anava dua jalur.

\section{Hasil dan Pembahasan}

Data hasil skala self-efficacy siswa dikumpulkan dan dianalisis untuk mengetahui tingkat kepercayaan diri siswa sebelum dan sesudah pemberian perlakuan pembelajaran, dan data diperoleh dari hasil pemberian skala self efficacy siswa pada saat sebelum dan sesudah proses pembelajaran. Sehingga akan didapat $\mathrm{n}$ - gainnya. Hasil analisis deskriptif terhadap data self- efficacy siswa disajikan pada Tabel 1 di bawah ini :

Tabel 1 hasil Rata- rata Sebelum dan Sesudah Self- Efficacy Siswa

\begin{tabular}{ccccc}
\hline \multirow{2}{*}{ Data } & \multicolumn{4}{c}{ Pembelajaran } \\
\cline { 2 - 5 } & Eksperimen 1 & \multicolumn{3}{c}{ Eksperimen 2 } \\
\cline { 2 - 5 } & Sebelum & Sesudah & Sebelum & Sesudah \\
\hline $\bar{x}$ & 74,8 & 85,5 & 72,37 & 84,9 \\
\hline \multicolumn{4}{c}{ Skor Ideal = 100 } \\
\hline
\end{tabular}

Berdasarkan Tabel 1 di atas terlihat

bahwa rata- rata sebelum pembelajaran antara kelas eksperimen 1 dan kelas eksperimen 2 masing - masing adalah 74,8 dan 72,37, rata- rata kelas tersebut terdapat perbedaan sebesar 2,43 . Hal ini menunjukkan bahwa rata- rata skor untuk kedua kelas hampir sama. Oleh karena itu masing -masing kelas boleh mendapat perlakuan yang berbeda. Jika terjadi perbedaan peningkatan self - efficacy pada akhir proses pembelajaran , maka perbedaan tersebut dapat dilihat sebagai akibat adanya perlakuan yang berbeda pada kedua kelas tersebut.

Selain itu, untuk hasil skala sebelum dan sesudah pembelajaran pada masing masing kelas terdapat perbedaan dimana pada kelas ekperimen 1 rata- rata hasil sesudah pembelajaran lebih tinggi daripada hasil rata- rata hasil sebelum pembelajaran yaitu $85,5>74,8$. Hal ini menunjukkan bahwa terdapat peningkatan rata- rata hasil tes self- efficacy siswa pada kelas eksperimen 1 sebesar 10,7. Demikian juga pada kelas eksperimen 2 bahwa ratarata hasil sesudah pembelajaran lebih tinggi daripada rata- rata hasil sebelum pembelajaran yaitu $84,9>72,37$. Hal ini menunjukkan bahwa terdapat peningkatan rata-rata hasil self- efficacy pada kelas eksperimen 2 sebesar 12,53. Berdasarkan peningkatan rata- rata tersebut, terlihat bahwa peningkatan rata- rata kelas eksperimen 1 lebih tinggi daripada peningkatan rata- rata kelas eksperimen 2 . Dengan demikian pembelajaran dengan pendekatan PMR memberikan dampak yang baik terhadap peningkatan selfefficacy belajar siswa.

Selanjutnya peningkatan rata-rata hasil self-efficacy belajar siswa antara hasil sebelum dan sesudah pembelajaran untuk kelas eksperimen 1 yang diberi pendekatan PMR dan kelas eksperimen 2 dengan pembelajaran penemuan terbimbing dapat dilihat pada Gambar 4.5 berikut :

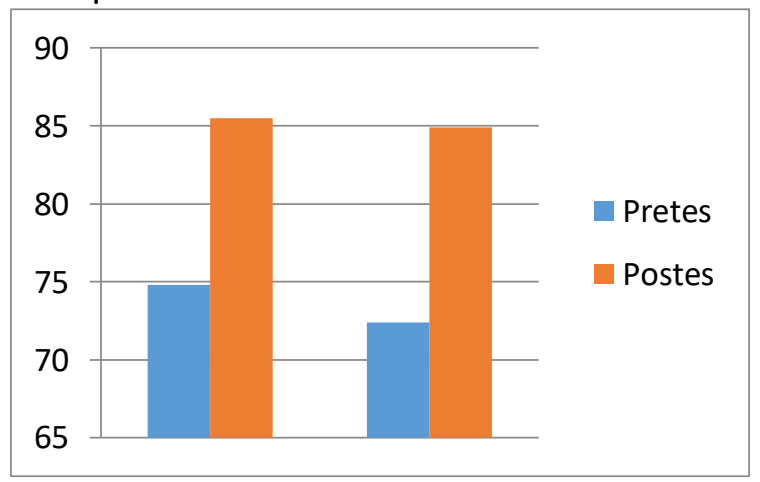

Gambar 1 Hasil Rata- rata Sebelum dan

Sesudah Self- Efficacy Belajar Siswa pada kedua Sampel

Berdasarkan gambar 1 dapat dilihat bahwa rata- rata nilai pada kelas eksperimen 1 lebih tinggi daripada rata- rat nilai pada kelas eksperimen 2, dapat kita simpulkan bahwa pembelajaran dengan pendekatan PMR lebih tinggi dibandingkan 
dengan Pembelajaran Penemuan Terbimbing.

Adapun peningkatan self- efficacy siswa dilihat dari hasil perhitungan $\mathrm{n}$ - gain pada kelas eksperimen 1 dan kelas eksperimen 2. Hasil perhitungan $\mathrm{n}$-gain pada kelas eksperimen 1 dan eksperimen 2 terdapat pada Tabel 2 berikut :

Tabel 2 Hasil Perhitungan N-Gain Self-efficacy

\begin{tabular}{lccc}
\hline \multirow{2}{*}{ Indikator } & $\begin{array}{l}\text { Data } \\
\text { Statisti } \\
\end{array}$ & $\mathbf{k}$ & \multicolumn{2}{c}{ Pembelajaran } \\
\cline { 3 - 4 } & & $\begin{array}{c}\text { Kelas } \\
\text { Eks 1 }\end{array}$ & $\begin{array}{c}\text { Kelas } \\
\text { Eksperime } \\
\mathbf{n ~ 2}\end{array}$ \\
\hline \multirow{2}{*}{ Tinggi } & $\bar{x}$ & 0,94 & 0,63 \\
& SD & 0,23 & 0,15 \\
Sedang & $\bar{x}$ & 0,44 & 0,47 \\
& SD & 0,22 & 0,13 \\
Rendah & $\bar{x}$ & 0,18 & 0,09 \\
Keseluruh & SD & 0,14 & 0,04 \\
an & $\bar{x}$ & 0,52 & 0,40 \\
\hline & SD & 0,05 & 0,32 \\
\hline
\end{tabular}

Berdasarkan Tabel 4.15 di atas, tampak secara keseluruhan bahwa rata-rat n-gain hasil tes kemampuan pemecahan masalah siswa pada kelas eksperimen 1 lebih tinggi daripada kelas eksperimen 2, yaitu $0,05>0,32$. Tingginya rata-rata $n$ gain hasil self-efficacy belajar siswa pada kelas eksperimen 1 menunjukkan bahwa peningkatan self-efficacy pada kelas eksperimen 1 lebih tinggi daripada peningkatan self-efficacy belajar siswa pada kelas eksperimen 2. Dengan demikian pemberian perlakuan pembelajaran dengan menggunakan pendekatan PMR memberikan peningkatan yang lebih baik atau lebih tinggi dibandingkan dengan pembelajaran Penemuan Terbimbing. $\urcorner$

Berdasarkan kategori Hake ( 1999), rata-rata self- efficacy belajar siswa kelas 1 eksperimen 1 pada kategori KAM tinggi dengan nilai 0,94 , kategori KAM sedang dengan nilai 0,44 termasuk dalam kategori $\mathrm{n}$ - gain sedang $(0,3<\mathrm{g} \leq 0,7)$, dan kategori KAM rendah dengan nilai 0,18 termasuk dalam kategori $\mathrm{n}$-gain rendah ( $\mathrm{g} \leq 0,3$ ).
Begitupun untuk kelas eksperimen 2 pada kategori KAM tinggi dengan nilai 0,63 , termasuk dalam kategori $n$-gain sedang $(0,3<\mathrm{g} \leq 0,7)$, sedangkan kategori KAM sedang nilai 0,47 dan kategori KAM rendah dengan nilai 0,09 termasuk dalam kategori $\mathrm{n}$-gain rendah ( $\mathrm{g} \leq 0,3$ ).

Selanjutnya akan ditampilkan gambar hasil n-gain berdasarkan KAM untuk kelas eksperimen 1 yang diberi pendekatan PMR dan kelas eksperimen 2 dengan Pembelajaran Penemuan Terbimbing dapat dilihat pada Gambar 2 berikut :

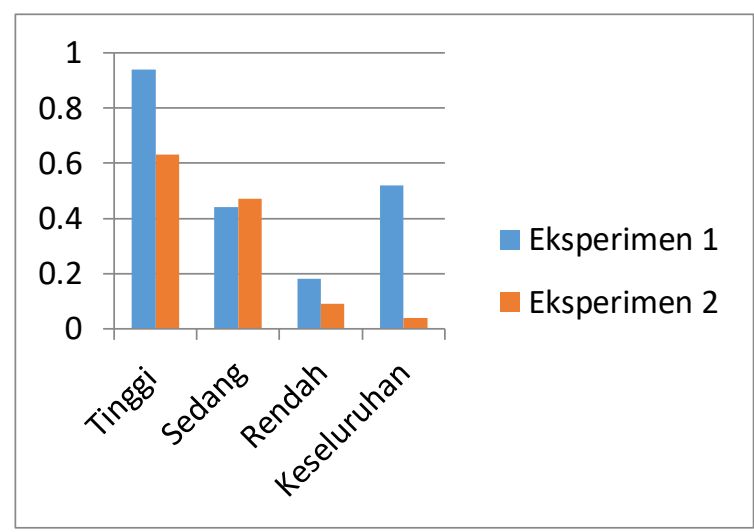

Gambar 2 di atas dapat lebih memperjelas perbedaan peningkatan selfefficacy belajar siswa berdasarkan kelas eksperimnen 1 dan kelas eksperimen2 untuk setiap kategori KAM. Dapat disimpulkan bahwa kelas eksperimen 1 memiliki peningkatan self-efficacy siswa yang lebih tinggi daripada kelas eksperimen 2, dengan arti terdapat perbedaan peningkatan self-efficacy siswa yang memperoleh pendekatan PMR dan Pembelajaran Penemuan Terbimbing. Selfefficacy adalah keyakinan orang tentang kemampuan mereka untuk menghasilkan tingkat kinerja yang ditunjukan dengan latihan pengaruh atas peristiwa yang mempengaruhi kehidupan mereka. Dan juga self-efficacy berupa bagaimana perasaan seseorang, cara berpikir, motivasi diri dan keinginan memiliki sesuatu. Berdasarkan hasil analisis data terhadap rata-rata setelah adanya pembelajaran kelas yang diajar dengan berbasis masalah dan kelas yang diajar dengan penemuan 
terbimbing, maka diperoleh skor skala untuk self-efficacy pada kedua kelas. Peningkatan rerata skor skala self-efficacy belajar siswa yang diajar dengan PMR adalah 0,52 dan rerata skor skala selfefficacy yang diajar dengan pembelajaran penemuan terbimbing adalah 0,40 .

Hasil perhitungan menunjukkan, selfefficacy dengan pendekatan PMR lebih baik daripada self-efficacy yang diberi pembelajaran penemuan Terbimbing. Dengan pendekatan PMR terjadi keyakinan terhadap kemampuan diri sendiri sehingga mampu menyelesaikan tugas yang spesifik.

Dari hasil analisis yang diperoleh bahwa skor rata-rata self-efficacy siswa untuk kelas eksperimen 1 dalam pembelajaran matematika terdapat peningkatan yang lebih besar dibandingkan dengan hasil perolehan skor untuk kelas eksperimen 2 yang menggunakan pembelajaran Penemuan Terbimbing.

\section{Simpulan}

Berdasarkan hasil analisis, temuan dan pembahasan yang telah dikemukakan pada bab sebelumnya diperoleh kesimpulan yaitu :Terdapat perbedaan peningkatan self-efficacy antara siswa yang diberi pembelajaran matematika dengan pendekatan PMR dan Pendekatan Penemuan Terbimbing. Sebelum pembelajaran antara kelas eksperimen 1 dan kelas eksperimen 2 masing - masing adalah 74,8 dan 72,37 , rata- rata kelas tersebut terdapat perbedaan sebesar 2,43. Hal ini menunjukkan bahwa rata- rata skor untuk kedua kelas hampir sama. Oleh karena itu masing -masing kelas boleh mendapat perlakuan yang berbeda. Jika terjadi perbedaan peningkatan self efficacy pada akhir proses pembelajaran , maka perbedaan tersebut dapat dilihat sebagai akibat adanya perlakuan yang berbeda pada kedua kelas tersebut. hasil skala sebelum dan sesudah pembelajaran pada masing - masing kelas terdapat perbedaan dimana pada kelas ekperimen 1 rata- rata hasil sesudah pembelajaran lebih tinggi daripada hasil rata- rata hasil sebelum pembelajaran yaitu $85,5>74,8$. Hal ini menunjukkan bahwa terdapat peningkatan rata- rata hasil tes self- efficacy siswa pada kelas eksperimen 1 sebesar 10,7. Demikian juga pada kelas eksperimen 2 bahwa rata- rata hasil sesudah pembelajaran lebih tinggi daripada rata- rata hasil sebelum pembelajaran yaitu 84,9 $>72,37$. Berdasarkan peningkatan rata- rata tersebut, terlihat bahwa peningkatan ratarata kelas eksperimen 1 lebih tinggi daripada peningkatan rata- rata kelas eksperimen 2 .

\section{Saran}

1. Peneliti menunjukkan bahwa pendekatan PMR dapat meningkatkan kemampuan pemecahan masalah matematika siswa dan self efficacy siswa.

2. Peneliti mengharapkan dengan pembelajaran ini mampu meningkatkan kualitas pendidikan matematika.

3. Bagi guru atau pihak lain yang ingin meningkatkan kemampuan pemecahan masalah matematika siswa dan self efficacy siswa dapat memperhatikan komponen model pembelajaran dan karakteristik dari materi pelajaran yang tingkatkan.

\section{Daftar Pustaka}

[1] Zulkarnain, I., \& Sari, N. A. (2016). Model Penemuan Terbimbing dengan Teknik Mind Mapping untuk Meningkatkan Kemampuan Pemahaman Konsep Matematis Siswa SMP. Edu-Mat: Jurnal Pendidikan Matematika, 2(2) 
Jurnal Edumaspul, 4 (1), Year 2020 - 287

(Weni Ariyanti Lubis, Suwarno Ariswoyo, Edi Syahputra)

[2] Midgett, C. W., \& Eddins, S. K. (2001). NCTM's principles and standards for school mathematics: Implications for administrators. NASSP Bulletin, 85(623), 35-42.

[3] Lijing, J., \& Yingnan, J. (2017). MultiInterpretation of Program for International Student Assessment (PISA). US-China Education Review, 7(2), 98-104.

[4] Usman, H., \& Akbar, R. P. S. (2006). Pengantar statistika.
[5] Bos, H. J. (1992). Hans Freudenthal (1905-1990). Historia Mathematica, 19(1), 106-108

[6] Persada, A. R. (2016). Pengaruh Model Pembelajaran Penemuan (Discovery Learning) Terhadap Kemampuan Koneksi Matematika Siswa (Studi Eksperimen Terhadap Siswa Kelas VII SMPN 2 Sindangagung Kabupaten Kuningan Pada Pokok Bahasan Segiempat). Eduma: Mathematics Education Learning and Teaching, 5(2), 23-33. 